\title{
KONTRIBUSI DAN EFEKTIVITAS PENERIMAAN PAJAK PARKIR TERHADAP PENDAPATAN ASLI DAERAH KOTA GORONTALO
}

\author{
Alma Meita Makausi ${ }^{1}$, Harijanto Sabijono ${ }^{2}$, Sherly Pinatik ${ }^{3}$ \\ 1,2,3 Jurusan Akuntansi, Fakultas Ekonomi dan Bisnis, Universitas Sam Ratulangi, Jl. Kampus Bahu, Manado, \\ 95115, Indonesia \\ E-mail : meytamakausi@yahoo.com
}

\begin{abstract}
Parking Tax is a regional tax which can also affect the increase of local revenue. Effectiveness and contribution of Parking Tax is one tool to measure the extent of Local Government achievement in collecting Parking Tax contributes to the region's original revenue is very important to develop a region. This study aims to (1) find out the percentage level of effectiveness of Parking Tax in Gorontalo City (2) find out how much the percentage of Parking tax revenue contribution to the Original Revenue of Gorontalo City. This study applies a descriptive qualitative analysis method. The result of research obtained by the Gorontalo City parking tax in 2014-2018 experienced a fluctuation with an average percentage of $84,95 \%$ entered the criteria quite effectively, and the parking tax in Gorontalo City contributed less to the orginal regional income because it had an average percentage of $0,06 \%$ of revenue from the Gorontalo City original income.
\end{abstract}

Keywords: potency; effectiveness; contribution; parking tax; original local govermment revenue

\section{PENDAHULUAN}

Negara Kesatuan Republik Indonesia dibagi menjadi beberapa provinsi dan setiap provinsi terdiri dari Kabupaten dan Kota guna untuk melakukan penyelenggaraan pembangunan nasional yang berkewajiban dan bertanggung jawab untuk menjaga kepentingan rakyat, memberikan kesejahteraan, keamanan, keadilan, pertahanan, maupun kecerdasan yang merata bagi rakyat Indonesia sesuai dengan Pancasila dan Undang-Undang Dasar tahun 1945.

Undang-Undang No. 28 tahun 2009 Tentang Pajak Daerah dan Retribusi Daerah, pasal I ayat 10 yang berbunyi pajak daerah adalah kontribusi wajib kepada daerah yang terutang oleh pribadi atau badan yang bersifat memaksa berdasarkan Undang-Undang, dengan tidak mendapatkan imbalan secara langsung dan digunakan untuk kepentingan daerah bagi sebesar-besarnya kemakmuran rakyat.

Pajak Parkir merupakan pajak yang dipungut melalui penyelenggaraan tempat parkir yang berada diluar badan jalan, yang disediakan oleh pokok usaha ataupun yang disediakan sebagai suatu badan usaha, yang bisa juga disediakan sebagai tempat untuk penitipan kendaraan bermotor oleh orang pribadi atau badan.

Di Kota Gorontalo terdapat beberapa tempat yang digunakan sebagai tempat parkir kendaraan yang telah dikenakkan pajak, misalnya terminal dan tempat penitipan kendaraan bermotor yang dijadikan suatu usaha dan biasanya dikelolah oleh perorangan maupun suatu badan. Dalam melakukan pemungutan pajak parkir Badan Keuangan Kota Gorontalo mengalami beberapa kendala, diantaranya wajib pajak terlambat membayar pajak atau menunggak, dan kurangnya pemahaman wajib pajak dalam membayar pajak terutang atau menunggak. Dalam hal ini Pajak parkir termasuk salah satu dari sumber pajak daerah yang berperan dalam peningkatan Pendapatan Asli Daerah Kota Gorontalo. 


\section{TINJAUAN PUSTAKA}

Definisi Pajak. Undang-Undang No. 16 Tahun 2009 Tentang Ketentuan Umum dan Tata Cara Perpajakan dijelaskan bahwa Pajak adalah kontribusi wajib kepada Negara yang terutang oleh orang pribadi atau badan yang bersifat memaksa berdasarkan Undang-Undang, dengan tidak mendapatkan imbalan secara langsung dan digunakan untuk keperluan Negara bagi sebesar-besarnya kemakmuran rakyat. Adapun dalam Undang-Undang No. 36 Tahun 2008 tentang Pajak Penghasilan yang dimaksud Pajak adalah iuran yang diterima atau diperoleh perkumpulan dari anggotanya yang terdiri dari Wajib Pajak yang menjalankan usaha atau pekerjaan bebas.

Fungsi Pajak. Mardiasmo (2011:1,2) Ada dua fungsi pajak, yaitu :

1. Fungsi Penerimaan (Budgeter)

Pajak berfungsi sebagai sumber dana yang diperuntukkan bagi pembiayaan pengeluaran-pengeluaran pemerintah.

2. Fungsi Mengatur (Reguler)

Pajak berfungsi sebagai alat untuk mengatur atau melaksanakan kebijakan dibidang sosial dan ekonomi.

Jenis pajak. Resmi $(2013: 7,8)$ Jenis pajak ada tiga, yaitu :

1. Menurut Golongan

a. Pajak langsung : Pajak yang harus dipikul atau ditanggung sendiri oleh wajib pajak dan tidak dapat dilimpahkan atau dibebankan kepada orang lain atau pihak lain. Pajak harus menjadi beban dari wajib pajak yang bersangkutan.

b. Pajak Tidak Langsung : Pajak yang pada akhirnya dapat dibebankan atau dilimpahkan kepada orang lain atau pihak ketiga. Pajak tidak langsung terjadi jika terdapat suatu kegiatan, peristiwa, atau perbuatan yang menyebabkan terutangnya pajak, misalnya terjadi penyerahan barang atau jasa.

2. Menurut Sifat

a. Pajak Subjektif : Pajak yang pengenaannya memperhatikan keadaan pribadi wajib pajak atau pengenaan pajak yang memperhatikan keadaan subjeknya.

b. Pajak Objektif : Pajak yang pengenaannya memperhatikan objeknya baik berupa benda, keadaan, perbuatan atau peristiwa yang mengakibatkan timbulnya kewajiban membayar pajak, tanpa memperhatikan keadaan pribadi subjek pajak (wajib pajak) maupun tempat tinggal.

3. Menurut Lembaga Pemungut

a. Pajak Negara (Pajak Pusat) : Pajak yang dipungut oleh pemerintah pusat dan digunakan untuk membiayai rumah tangga negara pada umumnya.

b. Pajak Daerah : Pajak yang dipungut oleh pemerintah daerah baik daerah tingkat I (Pajak Provinsi) maupun daerah tingkat II (Pajak Kabupaten/Kota) dan digunakan untuk membiayai rumah tangga daerah masing-masing

Pajak Daerah. Menurut Mardiasmo (2013:12) dalam Kobandaha dan Wokas, Pajak Daerah adalah iuran yang dilakukan oleh orang pribadi atau badan kepada daerah tanpa imbalan langsung yang seimbang, yang dapat dipaksakan berdasarkan peraturan perundangundangan yang berlaku, yang digunakan untuk membiayai penyelenggaraan pemerintahan daerah.

Undang-Undang No. 28 Tahun 2009 Tentang Pajak Daerah dan Retribusi Daerah Pasal 2 ayat 2 Jenis Pajak Daerah Kabupaten/Kota terdiri atas :
a. Pajak Hotel;
b. Pajak Restoran;
c. Pajak Hiburan;
d. Pajak Reklame;
e. Pajak Penerangan jalan; 
f. Pajak Mineral Bukan Logam dan Batuan;

g. Pajak Parkir;

h. Pajak Air Tanah;

i. Pajak Sarang Burung Walet;

j. Pajak Bumi dan Bangunan Perdesaan dan Perkotaan;

k. Bea Perolehan Hak atas Tanah dan Bangunan.

Pendapatan Asli Daerah (PAD). Wulandari dan Iryanie (2018 : 23) Pendapatan Asli Daerah (PAD) merupakan merupakan salah satu komponen dari anggaran pendapatan belanja daerah (APBD). Di dalam PAD dapat terlihat bagaimana suatu daerah bisa menggali sumbersumber pendapatan asli daerah baik berasal dari pajak daerah, retribusi daerah, hasil pengelolaan kekayaan milik daerah yang dipisahkan dan lain-lain PAD yang sah.

Sumber-Sumber Pendapatan Asli Daerah. Undang-Undang No. 23 Tahun 2004 pasal 1 ayat 18 Tentang Perimbangan Keuangan Antara Pemerintah Pusat dan Pemerintah Daerah dijelaskan bahwa Pendapatan Asli Daerah adalah pendapatan yang diperoleh daerah yang dipungut berdasarkan peraturan daerah sesuai dengan peraturan perundang-undangan. Sumber-sumber Pendapatan Asli Daerah terdiri atas beberapa komponen, yaitu :

1. Pajak Daerah

2. Retribusi Daerah

3. Hasil Pengelolaan Kekayaan Daerah

4. Lain-lain Pendapatan Asli Daerah

Pajak Parkir. Undang-Undang Nomor 28 tahun 2009 Tentang Pajak Daerah dan Retribusi Daerah, Pajak Parkir diatur dalam pasal 62 sampai pasal 66 berbunyi pajak parkir adalah pajak atas penyelenggaraan tempat parkir diluar badan jalan, baik yang disediakan berkaitan dengan pokok usaha maupun yang disediakan sebagai suatu usaha, termasuk penyediaan tempat penitipan kendaraan bermotor. Parkir adalah keadaan tidak bergerak suatu kendaraan yang,tidak bersifat sementara.

Objek Pajak Parkir. Anggoro (2017:201) Objek pajak parkir adalah penyelenggara tempat parkir diluar badan jalan, baik yang disediakan berkaitan dengan pokok usaha maupun yang disediakan sebagai salah satu usaha, termasuk penyediaan tempat penitipan kendaraan bermotor. Klasifikasi tempat parkir diluar badan jalan yang dikenakan Pajak Parkir adalah :

1. Gedung parkir;

2. Peralatan parkir;

3. Garasi kendaraan bermotor yang memungut bayaran; dan

4. Tempat penitipan kendaraan bermotor.

Perhitungan Pajak Parkir. Anggoro (2017:203) Besaran pokok pajak parkir yang terutang dihitung dengan cara mengalihkan tarif pajak dengan dasar pengenaan pajak. Secara umum perhitungan pajak parkir adalah sebagai berikut:

Pajak Terutang $=$ Tarif Pajak $x$ Dasar Pengenaan Pajak

$=$ Tarif Pajak x Jumlah Pembayaran atau yang Seharusnya

Dibayar Kepada Penyelenggara Tempat Parkir

Potensi. Dalam Kamus Umum Bahasa Indonesia, kata "potensi" mempunyai arti suatu kemampuan yang masih bias dikembangkan lebih lanjut. Untuk mengetahui potensi pemungutan pajak parkir digunakan rumus (Malombeke, 2016) :

Potensi Pemungutan Pajak Parkir $=\frac{100+\text { perhitungan rata-rata kenaikan }(\%)}{100}$

Efektivitas. Efektivitas merupakan hubungan antara keluaran dengan tujuan atau sasaran yang harus dicapai. Mahsun $(2012$ :187) Untuk mengetahui tingkat efektivitas pajak parkir digunakan rumus : 


$$
\text { Efektivitas }=\frac{\text { Realisasi Pajak Parkir }}{\text { Target Pajak Parkir }} \times 100 \%
$$

Tingkat kriteria efektitivitas sebagai berikut :

Tabel 1.Tingkat Efektivitas

\begin{tabular}{cc}
\hline Tingkat Efektivitas & Presentase \\
\hline Sangat Efektif & $>100 \%$ \\
Efektif & $>90-100 \%$ \\
Cukup Efektif & $>80-90 \%$ \\
Kurang Efektif & $>60-80 \%$ \\
Tidak Efektif & $<60 \%$ \\
\hline
\end{tabular}

Sumber : Mahmudi (2015)

Kontribusi. Manuputty et al (2019) Kontribusi adalah suatu hal yang diberikan bersama-sama bersama pihak lain untuk tujuan biaya atau kerugian tertentu. Kontribusi pajak daerah adalah perkiraan hasil/jumlah yang diperoleh dari sektor pajak disuatu daerah dibandingkan dengan jumlah total pendapatan asli daerah. Untuk mengetahui besarnya kontribusi pajak parkir digunakan rumus (Firdausy, 2017 :92) :

$$
\text { Kontribusi }=\frac{\text { Realisasi Penerimaan Pajak Parkir }}{\text { Penerimaan Pendapatan Asli Daerah }} \times 100 \%
$$

Tingkat kriteria presentase kontribusi sebagai berikut :

Tabel 2.Tingkat Kontribusi

\begin{tabular}{cc}
\hline Presentase & Kriteria \\
\hline $0,00 \%-10 \%$ & Tidak Berkontribusi \\
$10,10 \%-20 \%$ & Kurang berkontribusi \\
$20,10 \%-30 \%$ & Cukup berkontribusi \\
$30,10 \%-40 \%$ & Berkontribusi \\
$40,10 \%-50 \%$ & Sangat berkontribusi \\
\hline
\end{tabular}

Sumber : Depdagri, Kepmendagri No.690.900.327 (Lintong et al, 2018)

\section{METODE PENELITIAN}

Jenis Penelitian. Jenis penelitian ini menggunakan metode deskriptif kualitatif. Tempat penelitian dilakukan pada Badan Keuangan Kota Gorontalo dengan alamat Jl.Nani Wartabone, Ipilo, Kota Timur, Kota Gorontalo. Waktu pelaksanaan mulai dilaksanakan April 2019 sampai dengan selesai.

Jenis, Sumber dan Metode Pengumpulan Data. Jenis data dalam Penelitian ini menggunakan data kualitatif dan data kuantitatif. Data kualitatif berupa hasil wawancara mengenai sejarah dan struktur organisasi Badan Keuangan Kota Gorontalo dan data kuantitatif berupa Laporan Penerimaan Pajak Parkir dan penerimaan Pendapatan Asli Daerah (PAD) Kota Gorontalo. Sumber data yang digunakan dalam penelitian ini adalah data primer. Dalam hal ini, data primer yang diperoleh melalui hasil wawancara secara langsung dengan pihak Badan Keuangan Kota Gorontalo. Metode pengumpulan data adalah wawancara yang dilakukan secara langsung baik dengan pimpang maupun pegawai yang ada di Badan Keuangan Kota Gorontalo untuk memperoleh data-data berupa gambaran umum 
tentang Badan Keuangan Kota Gorontalo, laporan target dan realisasi pajak parkir dan penerimaan Pendapatan Asli Daerah (PAD) di Kota Gorontalo pad tahun 2014-2018.

Metode dan Proses Analisis. Penelitian ini bersifat kualitatif, berdasarkan data yang diperoleh berupa hasil dokumentasi dan wawancara peneliti menganalisis, serta melakukan perhitungan melalui rumus efektivitas dan kontribusi kemudian hasil data tersebut dijelaskan dan disimpulkan. Proses yang dilakukan dalam penelitian ini menggunakan tahap penelitian yang berhubungan dengan masalah yang diteiliti. Beberapa tahap tersebut yaitu sebagai berikut ini.

1. Menjelaskan secara umum tentang Badan Keuangan Kota Gorontalo, Pajak Parkir dan Pendapatan Asli Daerah (PAD) Kota Gorontalo.

2. Mengumpulkan data dan melakukan analisis data yang diperoleh mengenai data realisasi penerimaan pajak parkir dan realisasi penerimaan Pandapatan Asli Daerah (PAD) Kota Gorontalo pada tahun 2014-2018

3. Untuk mengetahui besarnya kontribusi realisasi penerimaan pajak parkir terhadap Pendapatan Asli Daerah di Kota Gorontalo pada tahun 2014-2018.

4. Untuk mengetahui tingkat efektivitas pajak parkir terhadap Pendapatan Asli Daerah di Kota Gorontalo tahun 2014-2018.

\section{HASIL PENELITIAN DAN PEMBAHASAN}

Gambaran Umum Objek Penelitian. Kota Gorontalo lahir pada hari kamis, 18 maret $1782 \mathrm{M}$ atau bertepatan dengan Kamis, 06 Syakban 1140 Hijriah. Tepat pada tanggal 16 Februari 2001 Kota Gorontalo secara resmi sebagai ibu kota Provinsi Gorontalo (UU Nomor 38 Tahun 2000 Pasal 7), namun sebagai daerah otonom Kota Gorontalo secara resmi terbentuk pada tanggal 20 Mei 1960 sebagai pelaksanaa UU No.29/1959 tentang pembentukan Dati II di Sulawesi. Sebelum terbentuknya Provinsi Gorontalo, Kota Gorontalo merupakan bagian dari Provinsi Sulawesi Utara. Gorontalo merupakan sebuah Kotapraja yang secara resmi berdiri sejak tanggal 20 Mei 1960, yang kemudian berubah menjadi Kotamadya Gorontalo pada tahun 1965. Nama Kotamadya Gorontalo ini dipakai hingga pada tahun 1999. Selanjutnya, sejak diberlakukan Undang-Undang Nomor 22 Tahun 1999 tentang Pemerintahan Daerah, di mana istilah Kotamadya sudah tidak dipakai lagi dan telah digantikan dengan Kota, maka Gorontalo pun menyesuaikan namanya menjadi Kota Gorontalo hingga sekarang.

Pembentukan Badan Keuangan untuk membantu Kepala Daerah dalam melaksanakan urusan pemerintahan dibidang keuangan yang menjadi kewenangan Daerah Kota Gorontalo dan Tugas Pembantuan yang diberikan kepada Daerah Kota Gorontalo. Badan Keuangan Kota Gorontalo terbentuk berdasarkan Peraturan Daerah Nomor 5 Tahun 2016 Tentang Pembentukan dan Susunan Perangkat Daerah dan Peraturan Walikota Gorontalo Nomor 49 Tahun 2016 Tentang Kedudukan, Susunan Organisasi, Tugas dan Fungsi serta Tata Kerja Badan Keuangan Kota Gorontalo. Badan Keuangan dibawah dan bertanggung jawab kepada Walikota Gorontalo melalui Sekretaris Daerah Kota Gorontalo. Kepala Badan Keuangan dalam melaksanakan tugasnya wajib menyelenggaran koordinasi, integrasi, dan singkronisasi baik dilingkungan masing-masing maupun antar satuan organisasi sesuai dengan tugas masing-masing

\subsection{Hasil Penelitian}

Target Dan Realisasi Penerimaan Pajak Parkir dan Pendapatan Asli Daerah Kota Gorontalo. Untuk memberikan gambaran yang lebih jelas atas hasil data pada penelitian, maka dalam tabel 4.1 akan dijelaskan mengenai target dan realisasi penerimaan pajak parkir Kota Gorontalo dan pada tabel 4.2 akan dijelaskan tentang target dan realisasi pendapatan asli daerah di Kota Gorontalo pada tahun 2014-2018. 


\begin{tabular}{cccrc}
\hline Tabel 3.Target dan Realisasi Pajak Parkir di Kota Gorontalo Tahun 2014-2018 \\
\hline $\begin{array}{c}\text { Tahun } \\
\text { Anggaran }\end{array}$ & $\begin{array}{c}\text { Target } \\
\text { Penerimaan } \\
\text { Pajak Parkir } \\
\text { (Rp) }\end{array}$ & $\begin{array}{c}\text { Realisasi } \\
\text { Penerimaan } \\
\text { Pajak Parkir } \\
(\text { Rp) }\end{array}$ & Selisih & Keterangan \\
\hline 2014 & $500.000 .000,00$ & $524.234 .700,00$ & $24.234 .700,00$ & Melebihi Taget \\
2015 & $850.000 .000,00$ & $850.000 .000,00$ & $(26.016 .000,00)$ & Tidak Mencapai \\
2016 & $1.000 .000 .000,00$ & $1.036 .906 .700,00$ & $36.906 .700,00$ & Melebihi Target \\
2017 & $1.750 .000 .000,00$ & $1.376 .884 .900,00$ & $373.115 .100,00$ & Tidak Mencapai \\
2018 & $3.000 .000 .000,00$ & $1.218 .953 .906,00$ & $(1.781 .046 .094,00)$ & Tidak Mencapai \\
\hline
\end{tabular}

Sumber data : Hasil olahan

Dari tabel 3 menunjukkan bahwa target pajak parkir setiap tahun 2014-2018 selalu meningkat, pada tahun 2015 target yang ditetapkan sebesar Rp.850.000.000,00 dan realisasi sebesar Rp. 850.000.000,00 tidak mencapai target, pada tahun 2017 target sebesar Rp. 1.750.000.000,00 dan realisasi sebesar Rp. 1.376.884.900,00 juga tidak mencapai target dan tahun 2018 target sebesar Rp. 3.000.000.000,00 realisasi sebesar Rp. 1.218.953.906,00 tidak mencapai target. Pajak parkir pada tahun 2015, 2017 dan 2018 tidak terealisasi karena target yang ditetapkan pemerintah daerah terlalu tinggi dari realisasi penerimaan pajak tahun sebelumnya. Selain itu, ada beberapa kendala yang ditemukan yaitu, wajib pajak tidak membayar pajak tepat waktu (menunggak) dan kurangnya pemahaman wajib pajak dalam membayar pajak yang menunggak.

Tabel 4. Target dan Realisasi Pendapatan Asli Daerah Kota Gorontalo Tahun 20142018

\begin{tabular}{cccc}
\hline Tahun & $\begin{array}{c}\text { Target Pendapatan Asli } \\
\text { Daerah (Rp) }\end{array}$ & $\begin{array}{c}\text { Realisasi Pendapatan } \\
\text { Asli Daerah (Rp) }\end{array}$ & Presentase (\%) \\
\hline 2014 & $150.586 .820 .147,00$ & $124.732 .780 .260,00$ & $78 \%$ \\
2015 & $161.643 .203 .408,00$ & $142.700 .996 .247,32$ & $88 \%$ \\
2016 & $191.207 .291 .450,00$ & $172.315 .775 .595,42$ & $90 \%$ \\
2017 & $237.521 .987 .575,00$ & $207.661 .191 .122,19$ & $87 \%$ \\
2018 & $220.343 .322 .064,00$ & $193.669 .459 .294,40$ & $88 \%$ \\
\hline
\end{tabular}

Sumber data : Badan Keuangan Kota Gorontalo

Dari tabel 4 menunjukkan penerimaan Pendapatan Asli daerah Kota Gorontalo tahun 2014-2018 tidak mencapai target yang ditetapkan karena sumber-sumber penerimaan pendapatan asli daerah lainnya tidak melebihi target.

\subsection{Pembahasan}

Perhitungan Kenaikkan Pajak Parkir dan Potensi Pemungutan Pajak Parkir. Berikut ini pada tabel 5 membahas hasil perhitungan kenaikkan pajak parkir dan pada tabel 6 membahas hasil perhitungan potensi pemungutan pajak parkir di Kota Gorontalo tahun 20142018. 


\begin{tabular}{crrr}
\hline \multicolumn{2}{l}{ Tabel 5. Perhitungan Kenaikkan Pajak Parkir di Kota Gorontalo } & \\
\hline Tahun & Total Penerimaan (Rp) & Kenaikan (Rp) & Kenaikan (\%) \\
\hline 2014 & $524.234 .700,00$ & & 36,37 \\
2015 & $823.984 .000,00$ & $299.749 .300,00$ & 20,53 \\
2016 & $1.036 .906 .700,00$ & $212.922 .700,00$ & 24,69 \\
2017 & $1.376 .884 .900,00$ & $339.978 .200,00$ & $-12,95$ \\
2018 & $1.218 .953 .906,00$ & $(157.930 .994,00)$ & 13,72 \\
\hline
\end{tabular}

Sumber data : Hasil olahan

Selanjutnya presentase (\%) kenaikan pajak parkir di Kota Gorontalo dapat dihitung sebagai berikut :

1. Kenaikan pajak parkir di Kota Gorontalo tahun 2014 ketahun 2015

$$
\frac{299.749 .300,00}{823.984 .000,00} \times 100 \%=36,37 \%
$$

2. Kenaikan pajak parkir di Kota Gorontalo tahun 2015 ketahun 2016

$$
\begin{gathered}
\frac{212.922 .700,00}{1.036 .906 .700,00} \times 100 \%=20,53 \% \\
\text { Rata-rata Kenaikkan }(\%) \quad 28,45
\end{gathered}
$$

3. Kenaikan pajak parkir di Kota Gorontalo tahun 2016 ketahun 2017

$$
\frac{339.978 .200,00}{1.376 .884 .900,00} \times 100 \%=24,69 \%
$$

4. Kenaikan pajak parkir di Kota Gorontalo tahun 2017 ketahun 2018

$$
\text { Rata-rata kenaikan }(\%) \begin{gathered}
1.218 .953 .906,00 \\
13,72 \%
\end{gathered}
$$$$
\underline{(157.930 .994,00)} \times 100 \%=12,95 \% \%
$$

Tahun $2016=$ Rp 1.036.906.700,00

Tahun $2017: \underline{128,45} \times 1.036 .906 .700,00=1.331 .906 .656,15$

$$
100
$$

Tahun $2018: \underline{128,45} \times 1.331 .906 .656,15=1.710 .834 .099,82$ 100

Selanjutnya, Perhitungan Potensi selama 5 tahun kedepan sebagai berikut :

Tahun $2018=\operatorname{Rp} 1.218 .953 .906,00$

Tahun $2019: \underline{113,72} \times 1.218 .953 .906,00=1.386 .194 .381,90$

$$
100
$$

Tahun $2020: \underline{113,72} \times 1.386 .194 .381,90=1.576 .380 .251,09$

100

Tahun $2021: \underline{113,72} \times 1.576 .380 .251,09=1.792 .659 .621,53$

100

Tahun $2022: \underline{113,72} \times 1.792 .659 .621,53=2.038 .612 .521,60$ 100

Tahun $2023: \underline{113,72} \times 2.038 .612 .521,60=2.318 .310 .159,56$ 100 


\begin{tabular}{cc}
\hline Tabel 6. Perhitungan Potensi Pemungutan Penerimaan Pajak parker di Kota Gorontalo \\
\hline Tahun & Potensi Penerimaan Pajak Parkir \\
\hline 2019 & $2.038 .612 .521,60$ \\
2020 & $1.576 .380 .251,09$ \\
2021 & $1.792 .659 .621,53$ \\
2022 & $2.038 .612 .521,60$ \\
2023 & $2.318 .310 .159,56$ \\
\hline
\end{tabular}

Sumber data : Hasil olahan

Jika dilihat dari potensi perhitungan penerimaan pajak parkir tahun 2014-2018 peningkatan pajak tidak stabil, karena setiap tahun target pajak parkir terus ditingkatkan akan tetapi realisasi penerimaannya masih tidak mencapai target. Dari hasil perhitungan potensi, seharusnya target penerimaan pajak parkir yang realistis tahun 2017 sebesar Rp.1.331.906.656,15 dan pada tahun 2018 Rp.1.710.834.099,82. Selanjutnya pada tabel 6 tingkat potensi pajak parkir tahun 2019-2023 sangat bervariasi.

Efektivitas Pajak Parkir Kota Gorontalo tahun 2014-2018. Berikut dibawah ini merupakan tabel efektivitas pajak parkir di Kota Gorontalo tahun 2014-2018.

Tabel 7. Efektivitas Pajak Parkir Kota Gorontalo Tahun 2014-2018

\begin{tabular}{ccccc}
\hline $\begin{array}{c}\text { Tahun } \\
\text { Anggaran }\end{array}$ & $\begin{array}{c}\text { Target Penerimaan } \\
\text { Pajak Parkir }(\mathbf{R p})\end{array}$ & $\begin{array}{c}\text { Realisasi } \\
\text { Penerimaan Pajak } \\
\text { Parkir }(\mathbf{R p})\end{array}$ & $\begin{array}{c}\text { Persentase } \\
\boldsymbol{\%}\end{array}$ & Kriteria Efektivitas \\
\hline 2014 & $500.000 .000,00$ & $524.234 .700,00$ & 104,84 & Sangat efektif \\
2015 & $850.000 .000,00$ & $823.984 .000,00$ & 96,93 & Efektif \\
2016 & $1.000 .000 .000,00$ & $1.036 .906 .700,00$ & 103,69 & Sangat efektif \\
2017 & $1.750 .000 .000,00$ & $1.376 .884 .900,00$ & 78,67, & Kurang efektif \\
2018 & $3.000 .000 .000,00$ & $1.218 .953 .906,00$ & 40,63 & Tidak efektif \\
& Rata-rata & & 84,95 & Cukup efektif \\
\hline
\end{tabular}

Sumber data : Hasil olahan

Berdasarkan tabel 7 pajak parkir untuk tahun 2014 menuai hasil cukup tinggi yang mampu melewati target yang harus dicapai sebesar 104,84\%, meskipun pada tahun 2015 mengalami penurunan sebesar 96,93\%, pada tahun 2016 meningkat kembali menjadi sebesar 103,69\% melebihi target yang harus dicapai. Dan pada tahun 2017 mengalami penurun kembali sebesar 78,67\% dengan kategori kurang efektif, namun penurunan terendah terjadi pada tahun 2018 hingga sebesar 40,63\% dengan kategori tidak efektif.

Kontribusi Pajak Parkir Kota Gorontalo tahun 2014-2018. Berikut dibawah ini merupakan tabel kontribusi pajak parkir di Kota Gorontalo tahun 2014-2018.

Tabel 8. Kontribusi Pajak Parkir Terhadap Pendapatan Asli Daerah Kota Gorontalo Tahun 2014-2018

\begin{tabular}{ccccl}
\hline Tahun & $\begin{array}{c}\text { Realisasi } \\
\text { Penerimaan Pajak } \\
\text { Parkir (Rp) }\end{array}$ & $\begin{array}{c}\text { Penerimaan } \\
\text { Pendapatan Asli Daerah } \\
(\text { Rp) }\end{array}$ & Kontribusi & \multicolumn{1}{c}{ Kriteria } \\
\hline 2014 & $524.234 .700,00$ & $124.732 .780 .260,00$ & $0,04 \%$ & Kurang Berkontribusi \\
2015 & $823.984 .000,00$ & $142.700 .996 .247,32$ & $0,05 \%$ & Kurang berkontribusi \\
2016 & $1.036 .906 .700,00$ & $172.315 .775 .595,42$ & $0,06 \%$ & Kurang Berkontribusi \\
2017 & $1.376 .884 .900,00$ & $207.661 .191 .122,19$ & $0,07 \%$ & Kurang Berkontribusi \\
2018 & $1.218 .953 .906,00$ & $193.669 .459 .294,40$ & $0,06 \%$ & Kurang Berkontribusi \\
& Rata-rata & & $0,06 \%$ & Kurang Berkontribusi \\
\hline
\end{tabular}

Sumber data : Hasil olahan 
Berdasarkan tabel 8 dapat dilihat dengan jelas bahwa setiap tahun realisasi penerimaan pajak parkir dan realisasi pendapatan asli daerah mengalami peningkatan, namun tidak mencapai target yang ditetapkan oleh pemerintah. Kontribusi yang diberikan oleh pajak parkir kepada pendapatan asli daerah di Kota Gorontalo tahun 2014 sebesar 0,04\%, tahun 2015 sebesar $0,05 \%$, tahun 2016 sebesar $0,06 \%$, tahun 2017 sebesar 0,07\%, dan tahun 2018 sebesar 0,06\%. Dari tahun 2014-2018 rata-rata kontribusinya sebesar 0,06\% terhadap pendapatan asli daerah.

\section{KESIMPULAN DAN SARAN}

\subsection{Kesimpulan}

Berdasarkan hasil dan pembahasan yang dikemukakan pada bab sebelumnya, peneliti mengambil kesimpulan sebagai berikut :

1. Potensi pemungutan pajak parkir tahun 2014-2018 tidak stabil meskipun penerimaan pajak parkir pada setiap tahun meningkat akan tetapi tidak mencapai target yang ditetapkan pemerintah Kota Gorontalo, sedangkan potensi pemungutan pajak parkir 5 (lima) tahun mendatang, yaitu tahun 2019-2023 bervariasi.

2. Tingkat efektivitas penerimaan Pajak Parkir di Kota Gorontalo pada tahun 2014-2018 dengan rata-rata sebesar 84,95\% masuk dalam kriteria "Cukup Efektif".

3. Secara keseluruhan kontribusi Pajak Parkir Kota Gorontalo Periode 2014-2018 memberikan kontribusi rata-rata sebesar $0,06 \%$ dengan kriteria "kurang berkontribusi".

\subsection{Saran}

Berdasarkan kesimpulan yang telah dilkemukakan, maka peneliti memberikan saran yang dapat dijadikan bahan pertimbangan dalam menentukan kebijakan yang berhubungan dengan efektivitas dan kontribusi Pajak Parkir terhadap PAD Kota Gorontalo, yaitu sebagai berikut :

a. Meningkatkan kegiatan pendataan atau pendaftaran potensi sumber pajak yang ada didaerah serta penagihan penyetoran pajak yang belum dibayar (pembayaran yang menunggak).

b. Melakukan sosialisasi untuk memberikan arahan dan bimbingan kepada wajib pajak dalam rangka mempermudah wajib pajak melakukan pembayaran yang terutang serta melakukan sosialisasi untuk meningkatkan kesadaran masyarakat untuk membayar pajak.

c. Melakukan peninjauan kembali dalam proses pemungutan pajak parkir dan melakukan upaya-upaya dalam menangani kendala yang terjadi dilapangan misalnya memperketat pemungutan pajak parkir.

\section{DAFTAR PUSTAKA}

Anggoro, D. D. (2017). Pajak daerah dan retribusi daerah. Cetakan Pertama. Malang: Penerbit UB Press.

Firdausy, C. M. (2017). Optimalisasi kebijakan pemerintah daerah. Jakarta: Yayasan Pustaka Bogor Indonesia.

Kobandaha, R., \& Wokas, H. R. N. (2016). Analisis efektivitas kontribusi dan potensi pajak reklame dan pajak hotel terhadap pendapatan asli daerah kota kotamobagu. Jurnal EMBA, 5(1), 1461-1472. http://ejounal.unsrat.ac.id/index.php/emba/article/view/11767

Lintong, F., Sabijono, H., \& Kalalo M. Y. B. (2018). Analisis efektivitas dan kontribusi pajak bumi dan bangunan pedesaan dan perkotaan (PBB-P2) terhadap peningkatan penerimaan pendapatan asli daerah di Kabupaten Minahasa Selatan dan Kota Manado. 


\begin{tabular}{llllll}
\hline Going Concern: & Jurnal & Riset & Akuntansi, & 13(4),
\end{tabular}
http://ejournal.unsrat.ac.id/index.php/gc/artictle/view/20989/20676

Mahmudi. (2015). Manajemen kinerja sektor publik. Edisi 2. Yogyakarta: UPP STM.YKPN.

Mahsun, M. (2012). Pengukuran kinerja sektor publik. Edisi Pertama. Cetakan Ketiga. Yogyakarta: BPEF.

Malobeke, N. (2016). Analisis potensi dan efektivitas pemungutan pajak parkir di kabupaten $\begin{array}{llll}\text { minahasa utara. Jurnal } & \text { EMBA, }\end{array}$ http://ejounal.unsrat.ac.id/index.php/emba/article/view/11767

Manuputty, W. J., Saerang, D. P. E., \& Alexander, S. W. (2019). Analisis efektivitas kinerja Dan kontribusi retribusi pemakaian kekayaan daerah terhadap pendapatan asli daerah. Going Concern: Jurnal Riset Akuntansi, 14(1), 110-114. http://ejounal.unsrat.ac.id/index.php/emba/article/view/11767

Mardiasmo. (2011). Perpajakan. Edisi Revisi. Yogyakarta: Penerbit Andi.

Resmi, S. (2013). Perpajakan: Teori dan khasus. Edisi Enam. Jakarta: Salemba Empat.

Undang-Undang Nomor 16 Tahun 2009 Tentang Ketentuan Umum dan Tata Cara Perpajakan.

Undang-Undang Nomor 23 Tahun 2004 Tentang Perimbangan Keuangan Antara Pemerintah Pusat dan Pemerintah Daerah.

Undang-Undang Nomor 28 Tahun 2009 Tentang Pajak Daerah dan Retribusi Daerah.

Undang-Undang Nomor 36 Tahun 2008 Tentang Pajak Penghasilan.

Wulandari, P. A., \&Irynie, E. (2018). Pajak daerah dalam pendapatan asli. Cetakan Pertama. Yogyakarta: Deepublish. 